\title{
Structural Properties of Baked Clay Bricks Fired with Alternate Fuels
}

\author{
Nawab Ali Lakho, Muhammad Auchar Zardari* \\ Department of Civil Engineering, Quaid-e-Awam University of Engineering, Science and Technology, Nawabshah, Pakistan \\ Email: *muhammad.auchar@quest.edu.pk
}

How to cite this paper: Lakho, N.A. and Zardari, M.A. (2016) Structural Properties of Baked Clay Bricks Fired with Alternate Fuels. Engineering, 8, 676-683. http://dx.doi.org/10.4236/eng.2016.810061

Received: August 29, 2016

Accepted: October 7, 2016

Published: October 10, 2016

Copyright (C) 2016 by authors and Scientific Research Publishing Inc. This work is licensed under the Creative Commons Attribution International License (CC BY 4.0).

http://creativecommons.org/licenses/by/4.0/

\begin{abstract}
Coal is used as a traditional fuel for firing of clay bricks in kilns. The cost of coal is high and is increasing continuously. This paper describes the effect of alternate fuels on compressive strength, water absorption and density of fired clay bricks. The alternate fuels used in this study were 1) rapeseed husk (Type I), 2) combination of sugarcane-bagasse, rice husk and used clothes (Type II) and 3) coal (Type III). The results show that compressive strength of bricks fired using Type I and Type II fuels was decreased to $11 \%$ and $7 \%$, respectively, compared to those fired with coal. However, the values of water absorption and density of bricks fired with Type I and Type II fuels were almost same as exhibited by those baked with coal. This study shows that a saving of $25 \%$, and $18 \%$ could be achieved when the bricks were fired using Type I and Type II fuels, respectively, compared to those fired with coal.
\end{abstract}

\section{Keywords}

Baked Clay Bricks, Compressive Strength, Water Absorption, Density, Alternate Fuels, Coal

\section{Introduction}

Baked clay bricks are generally used as a walling material in buildings. Commercially the clay bricks are fired in a kiln at a temperature of $1000^{\circ} \mathrm{C}$ [1]-[3]. Thus, a huge amount of fuel is needed to fire clay bricks. Traditionally, coal is used as fuel for firing of clay bricks in the kilns [4]. But, the cost of coal is high. Therefore, the use of coal as a fuel results in the increase of the cost of bricks. Consequently, the cost of construction of buildings will be increased. In order to reduce the cost of baked clay bricks, alternative and low cost fuels are to be sought [5]-[13]. The structural properties of baked clay bricks depend upon firing temperature and firing time [3].

Rice husk, rapeseed husk and sugarcane-bagasse are agricultural byproducts, of 
which rapeseed husk is generally disposed-off at once from an agricultural farm in order to prepare seed bed for the next crop. Rice husk and sugarcane-bagasse are produced as byproducts at rice mills and sugar mills, respectively. When these byproducts are accumulated in vast quantities, they need to be dumped. These byproducts are available at very low cost. Usual practice in Sindh Pakistan is that these byproducts are used as a fuel in kilns, as an alternate to coal, for baking of clay bricks. In addition, used clothes are generally dumped with municipal solid waste. This may require more space for dumping. In order to solve this problem, the used clothes are also utilized as an alternate fuel in the kilns for firing of clay bricks.

If the above mentioned fuels are utilized for firing of bricks, the cost of firing could be reduced and the problem of safe disposal could be resolved. But, it is interesting to investigate whether the structural properties of bricks would be affected if they are fired with these alternate fuels instead of coal. The authors are of the opinion that no such study is reported in the literature. For this purpose, an experimental programme was undertaken to investigate the effect of these alternate fuels on compressive strength, density and water absorption of baked clay bricks. The fuels used for firing of bricks were 1) rapeseed husk (Type I) and 2) mixture of sugarcane-bagasse, rice husk and used clothes (Type II). The results of structural properties of bricks fired with these alternate fuels were compared with those of the bricks fired with coal (Type III).

\section{Materials and Methods}

\subsection{Manufacturing of Baked Clay Bricks}

The study was conducted at a commercial Hoffman's kiln (Figure 1) situated in the vicinity of Hala, district Matiari, Sindh, Pakistan. On average, this kiln produces about 30,000 baked clay bricks per day. For this purpose, large amount of clay is needed at the site of the kiln for casting of bricks. Clay was collected from a site about ten kilometers away from the kiln. Clay was provided by the contractor and dumped at the site of kiln (Figure 2). The quantity of water added was about $24 \%$ of clay to form a workable paste for casting of the bricks (Figure 3). A thin layer of pit-sand was spread on the surface of level ground to put the freshly cast bricks for drying (Figure 4). After the bricks were dried in sun for four days, they were collected and placed in the kiln for firing (Figure 5). Three batches of clay bricks were fired, each with 1) rapeseed husk (Type I), 2) sugarcane-bagasse, rice husk and used clothes (Type II) and 3) coal (Type III). The bricks were fired at a temperature of $1000^{\circ} \mathrm{C}$ in kiln. The time of firing was two hours, two and half hours, and three hours when the fuels were Type I, Type II, and Type III, respectively. After firing, bricks were collected from each batch and tested for compressive strength, density and water absorption.

\subsection{Testing Programme}

The compressive strength and water absorption of bricks was tested in accordance with ASTM C67 [14]. Compressive strength of the bricks was tested in the Universal Testing Machine. Half bricks were cut along the length using cutter machine (Figure 6). These 


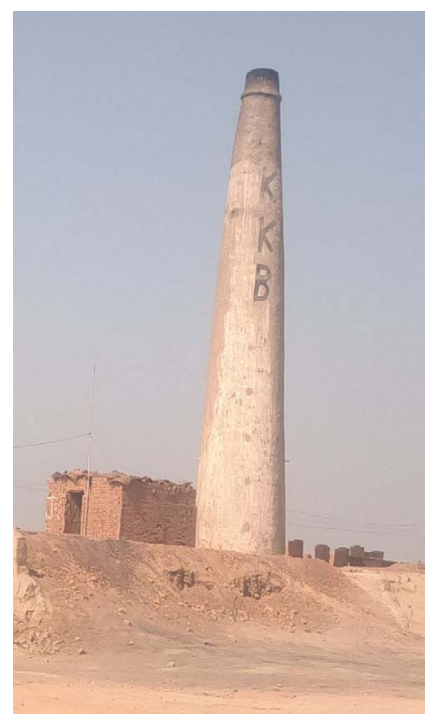

Figure 1. A view of a commercial Hoffman kiln.

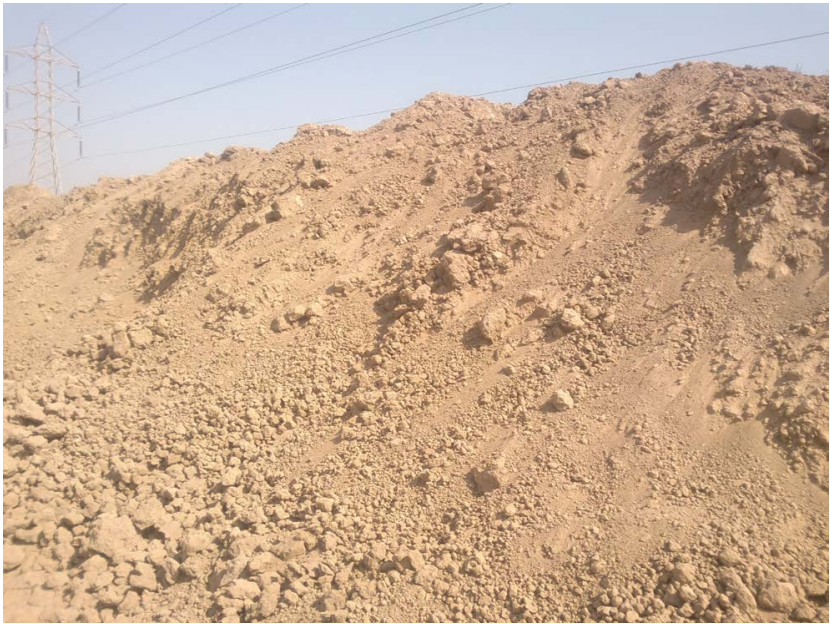

Figure 2. Clay is being dumped for casting of bricks.

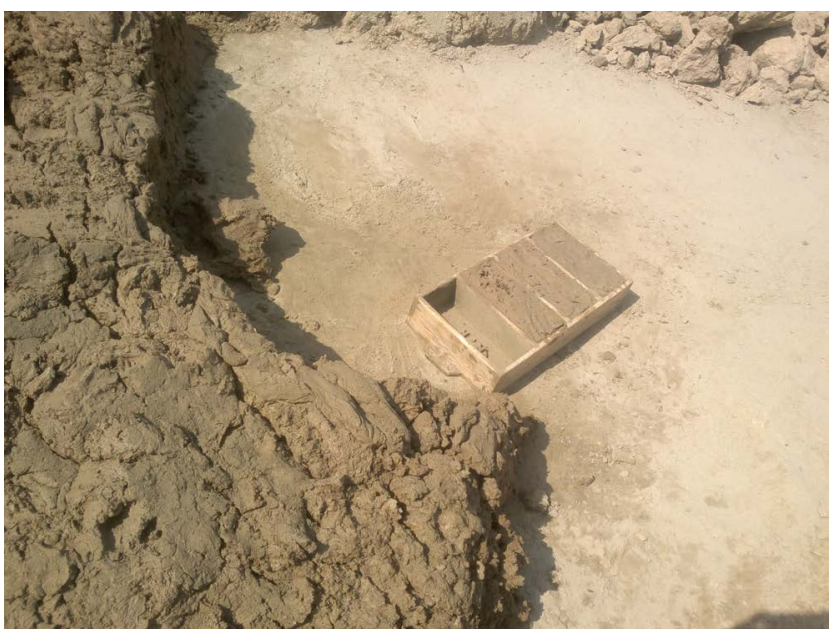

Figure 3. Moist clay paste prepared for casting of bricks. 


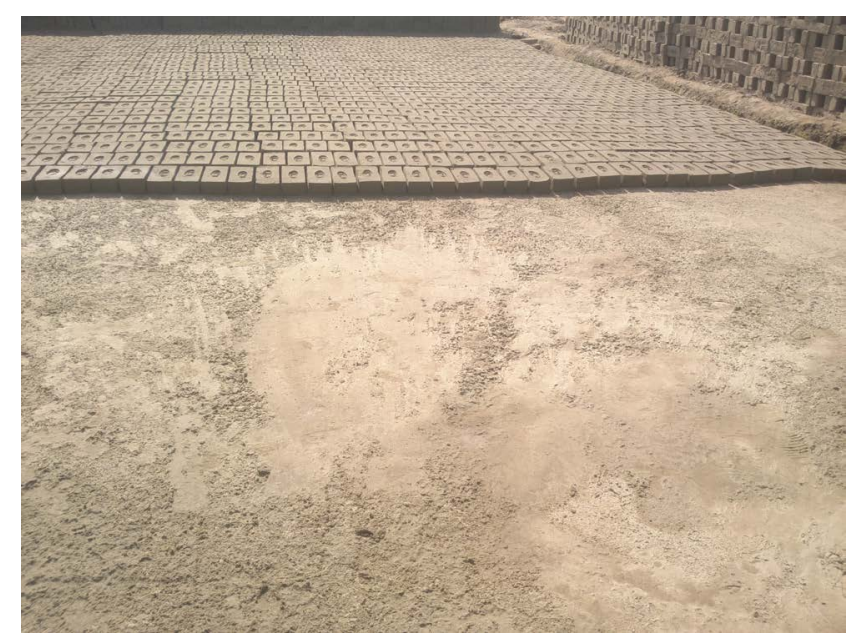

Figure 4. Clay bricks are being placed on ground for drying.

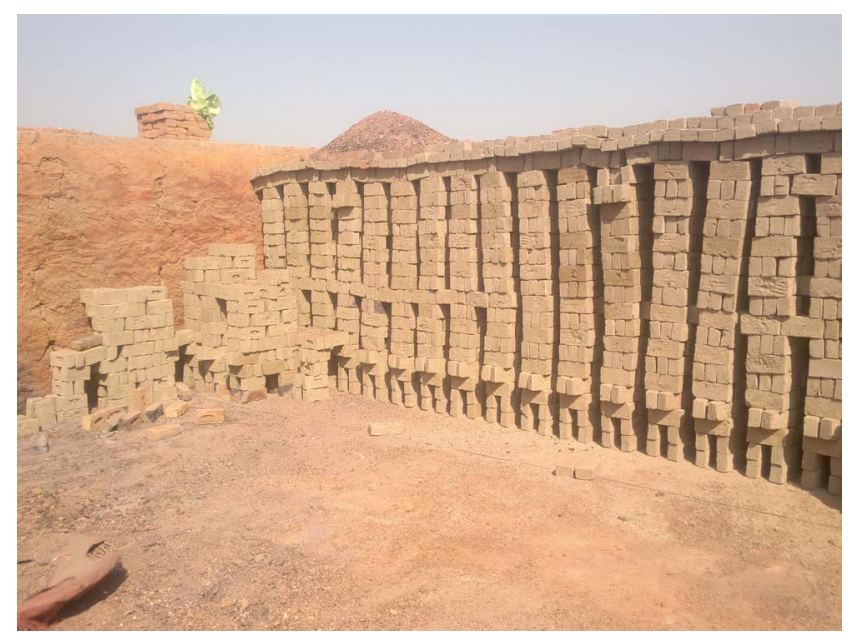

Figure 5. Sun dried clay bricks are being placed for firing in kiln.

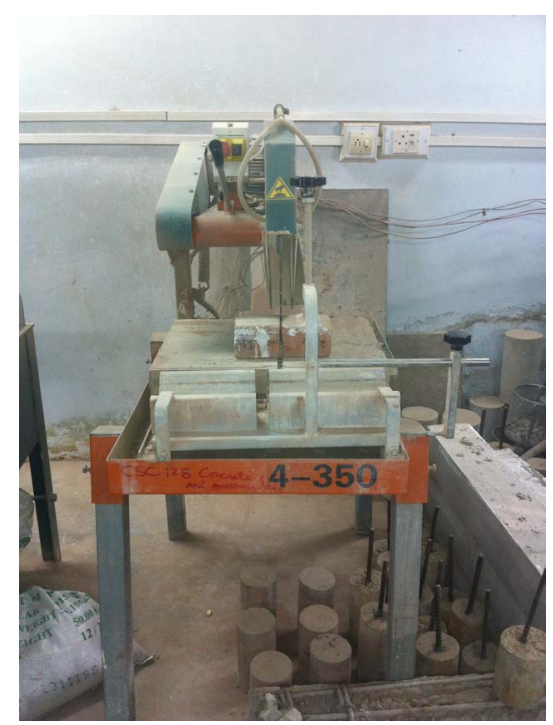

Figure 6. A baked clay brick is being cut into two halves using cutter machine. 


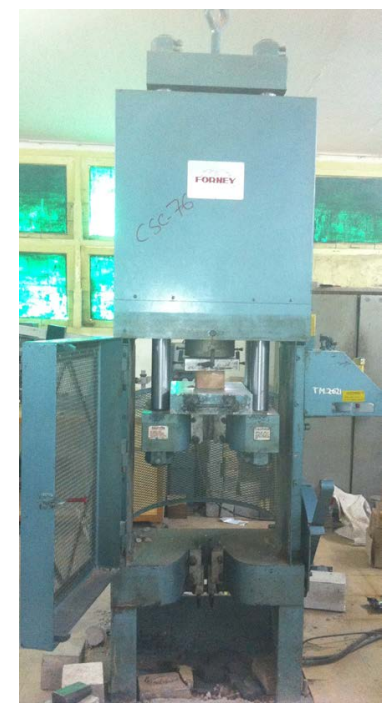

Figure 7. A baked clay brick specimen is being tested for compressive strength in Universal Testing Machine.

brick specimens were used for testing of compressive strength (Figure 7). To determine water absorption, the brick specimens were immersed in clean water for 24 hours. Surface water was wiped off with damp cloth and the brick specimens were weighed.

\section{Results and Discussions}

Three batches of clay bricks were fired using different fuels, i.e. 1) rapeseed husk (Type I), 2) combination of sugarcane-bagasse, rice husk and used clothes (Type II) and 3) coal (Type III). The bricks were tested for compressive strength, apparent density, and water absorption ratio. To conduct each of the tests mentioned above, ten samples were taken from each batch of baked clay bricks fired with different fuels.

\subsection{Compressive Strength of Baked Clay Bricks}

The values of the compressive strength of the bricks fired with different fuels are presented in Table 1. The results show that the compressive strength of bricks fired with Type I and Type II fuels is about 11\%, and 7\% lower than those baked with coal, respectively.

\subsection{Water Absorption and Density of Bricks}

The average values of water absorption and density of the bricks fired using different types of fuels are given in Table 1 . The results show that there is no significant difference in values of water absorption and density of bricks fired with alternate fuels compared to those baked with coal. The values of water absorption of the bricks mentioned in this study are in accordance with IS 3495 (Part 2): 1992 [15]. The criteria mentioned in this standard state that water absorption of the bricks immersed in water for 24 hours should not be more than $20 \%$ of the dry weight of the baked clay bricks having compressive strength up to $12.5 \mathrm{MPa}$. 
Since the average density of baked clay bricks is about $2000 \mathrm{~kg} / \mathrm{m}^{3}$ depending upon the method of manufacture, specific gravity of the clay, water added in the clay at the time of casting and firing temperature [3]. The values of the density of baked clay bricks described in this study are on average $23 \%$ lower than the average density of baked clay bricks.

It is to be noted that the difference in structural properties (compressive strength, water absorption and density) of baked clay bricks may be attributed to time of firing. The more the time of firing, the better were the structural properties of baked clay bricks.

\subsection{Saving in Cost of Bricks Fired with Alternate Fuels}

The cost of materials and fuels for manufacturing of clay bricks are presented in Table 2. The labour charges for manufacturing of bricks are given in Table 3. It is observed

Table 1. Effect of different fuels, used for firing, on structural properties of baked clay bricks.

\begin{tabular}{cccccc}
\hline S. No & Type of fuel & $\begin{array}{c}\text { Compressive } \\
\text { strength } \\
(\mathrm{MPa})\end{array}$ & $\begin{array}{c}\text { Decrease in } \\
\text { compressive strength (\%) } \\
\text { of bricks compared } \\
\text { with those fired with coal }\end{array}$ & $\begin{array}{c}\text { Water } \\
\text { absorption }\end{array}$ & $\begin{array}{c}\text { Density } \\
\left(\mathrm{kg} / \mathrm{m}^{3}\right)\end{array}$ \\
\hline 1 & Rapeseed husk (Type I) & 12.5 & 11 & 20 & 1533 \\
2 & $\begin{array}{c}\text { Sugarcane-bagasse, rice husk } \\
\text { and used clothes (Type II) }\end{array}$ & 13 & 7 & 18 & 1565 \\
3 & $\quad$ Coal (Type III) & 14 & 0 & 17 & 1578 \\
\hline
\end{tabular}

Table 2. Cost of materials and fuels used for manufacturing of clay bricks.

\begin{tabular}{ccc}
\hline S. No & Item & Cost per 1000 bricks (PKR) \\
\hline 1 & Clay & 250 \\
2 & Pit-sand & 60 \\
3 & Water & 50 \\
4 & Rent of the kiln & 46 \\
5 & Rapeseed husk (Type I) & 800 \\
6 & Sugarcane-bagasse, rice husk and used clothes (Type II) & 1000 \\
7 & Coal (Type III) & 1500 \\
\hline
\end{tabular}

Table 3. Cost of labour required for casting and firing of clay bricks.

\begin{tabular}{ccc}
\hline S. No & Type of work & Cost per 1000 bricks (PKR) \\
\hline 1 & Casting of bricks & 500 \\
2 & Loading of bricks in the kiln & 200 \\
3 & Unloading of bricks from the kiln & 100 \\
4 & Priming of the kiln & 14 \\
5 & Service and maintenance charges & 60 \\
\hline
\end{tabular}


Table 4. Total cost of manufacturing of 1000 bricks fired with alternate fuels.

\begin{tabular}{cccc}
\hline S. No & Type of fuel & $\begin{array}{c}\text { Total cost of } 1000 \\
\text { bricks (PKR) }\end{array}$ & $\begin{array}{c}\text { Saving in cost of 1000 bricks (\%) } \\
\text { compared with those fired with coal }\end{array}$ \\
\hline 1 & Rapeseed husk (Type I) & 2080 & 25 \\
2 & $\begin{array}{c}\text { Sugarcane-bagasse, rice husk and } \\
\text { used clothes (Type II) }\end{array}$ & 2280 & 18 \\
3 & Coal (Type III) & 2780 & 0 \\
\hline
\end{tabular}

from Table 2 and Table 3 that the cost of materials and labour charges per 1000 bricks excluding fuel charges is $1280 \mathrm{PKR}$. Total cost of fuel, materials and labour charges per 1000 bricks when fired using different fuels is described in Table 4 .

\section{Conclusions}

A study was conducted to investigate the effect of firing, using alternate fuels, on structural properties of baked clay bricks. The clay bricks were fired using the following fuels: 1) rapeseed husk (Type I), 2) combination of sugarcane-bagasse, rice husk and used clothes (Type II) and 3) coal (Type III). Following conclusions can be drawn:

1) The bricks fired with Type I and Type II fuels exhibited compressive strength as high as $89 \%$ and $93 \%$ of those baked with coal, respectively.

2) The values of water absorption and density of bricks fired with Type I and Type II fuels were almost similar to those fired with coal.

3) Saving in cost of bricks fired using Type I and Type II fuels was about $25 \%$ and $18 \%$, respectively, as compared to those fired with coal.

4) Besides temperature, the time of firing is an important parameter that governs the structural properties of baked clay bricks. It is suggested to investigate the effect of time of firing using these fuels to achieve economy.

\section{Acknowledgements}

The authors would like to thank Quaid-e-Awam University of Engineering, Science and Technology Nawabshah, for providing access to the Structural Engineering Laboratory to conduct the tests mentioned in this study.

\section{References}

[1] Karaman, S., Gunal, H. and Gokalp, Z. (2012) Variation of Clay Brick Colors and Mechanical Strength as Affected by Different Firing Temperatures. Scientific Research and Essays, 7, 4208-4212.

[2] Karaman, S., Gunal, H. and Ersahin, S. (2006) Assessment of Clay Bricks Compressive Strength Using Quantitative Values of Colour Components. Construction and Building Materials, 20, 348-354. http://dx.doi.org/10.1016/j.conbuildmat.2004.11.003

[3] Karaman, S., Ersahin, S. and Gunal, H. (2006) Firing Temperature and Firing Time Influence on Mechanical and Physical Properties of Clay Bricks. Journal of scientific and Industrial Research, 65, 153-159.

[4] Ghauri, M.A., Anwar, M.A., Akhtar, N., Haider, R. and Tawab, A. (2009) Status of Coal 
Biotechnology in Pakistan. Advanced Materials Research, 71-73, 513-516.

http://dx.doi.org/10.4028/www.scientific.net/AMR.71-73.513

[5] Bhutto, A.W., Bazmi, A.A. and Zahedi, G. (2011) Greener ENERGY: Issues and Challenges for Pakistan-Biomass Energy Prospective. Renewable and Sustainable Energy Reviews, 15, 3207-3219. http://dx.doi.org/10.1016/j.rser.2011.04.015

[6] Mirza, U.K., Ahmad, N. and Majeed, T. (2008) An Overview of Biomass Energy Utilization in Pakistan. Renewable and Sustainable Energy Reviews, 12, 1988-1996. http://dx.doi.org/10.1016/j.rser.2007.04.001

[7] Jan, I., Khan, H. and Hayat, S. (2012) Determinants of Rural Household Energy Choices: An Example from Pakistan. Polish Journal of Environmental Studies, 21, 635-641.

[8] Tahir, S.N.A., Rafique, M. and Alaamer, A.S. (2010) Biomass Fuel Burning and Its Implications: Deforestation and Greenhouse Gases Emissions in Pakistan. Environmental Pollution, 158, 2490-2495. http://dx.doi.org/10.1016/j.envpol.2010.03.017

[9] Amur, G.Q. and Bhattacharya, S.C. (1999) A Study of Biomass as a Source of Energy in Pakistan. International Energy Journal, 21, 25-36.

[10] Butt, S., Hartmann, I. and Lenz, V. (2013) Bioenergy Potential and Consumption in Pakistan. Biomass and Bioenergy, 58, 379-389. http://dx.doi.org/10.1016/j.biombioe.2013.08.009

[11] Darain, K.M., Rahman, A.B.M.S., Ahsan, A., Islam, A.B.M. and Yusuf, B. (2013) Brick Manufacturing Practice in Bangladesh: A Review of Energy Efficacy and Air Pollution Scenarios. Journal of Hydrology and Environment Research, 1, 60-69.

[12] Tahir, S.N.A. and Rafique, M. (2009). Emission of Greenhouse Gases (GHGs) from Burning of Biomass in Brick Kilns. Environmental Forensics, 10, 265-267. http://dx.doi.org/10.1080/15275920903347487

[13] Sahito, A.R., Mahar, R.B., Memon, M.A. and Brohi, K.M. (2012) Assessment of Waste Agricultural Biomass for Prevailing Management, Quantification and Energy Potential at Sanghar Pakistan. Waste and Biomass Valorization, 3, 275-284. http://dx.doi.org/10.1007/s12649-012-9132-8

[14] ASTM C67-14 (2014) Standard Test Methods for Sampling and Testing Brick and Structural Clay Tile. ASTM International, West Conshohocken, PA.

[15] IS 3495 (Part 2) (1992) Methods of Tests of Burnt Clay Building Bricks. Bureau of Indian Standards Manak Bhavan, New Delhi. 
Submit or recommend next manuscript to SCIRP and we will provide best service for you:

Accepting pre-submission inquiries through Email, Facebook, LinkedIn, Twitter, etc.

A wide selection of journals (inclusive of 9 subjects, more than 200 journals)

Providing 24-hour high-quality service

User-friendly online submission system

Fair and swift peer-review system

Efficient typesetting and proofreading procedure

Display of the result of downloads and visits, as well as the number of cited articles

Maximum dissemination of your research work

Submit your manuscript at: http://papersubmission.scirp.org/

Or contact eng@scirp.org 